\title{
Geochemical and micropaleontological evidence of recent hydrological changes in sedimentary records of Jiquilisco Bay, El Salvador
}

\section{Evidencias geoquímicas y micropaleontológicas de cambios hidrológicos recientes en registros sedimentarios de la bahía de Jiquilisco, EI Salvador}

\author{
Oscar Armando Amaya-Monterrosa ${ }^{1}$, María Luisa Machain-Castillo ${ }^{2 *}$, Ana Carolina Ruiz-Fernández ${ }^{3}$, \\ Joan Albert Sanchez-Cabeza ${ }^{2}$, Arturo Carranza-Edwards², Alejandro Cearreta ${ }^{4}$, \\ Mayumy Amparo Cabrera-Ramírez ${ }^{5}$, Jaime Espinoza-Navarrete ${ }^{1}$, Estephanie Meza-Guerrero ${ }^{6}$, \\ Libia Hascibe Pérez-Bernal ${ }^{3}$, Alejandro Rodríguez-Ramírez ${ }^{2}$ \\ ${ }^{1}$ Laboratorio de Toxinas Marinas, Universidad de El Salvador, Final 25 Avenida Norte, Ciudad Universitaria, \\ San Salvador, El Salvador. \\ 2 Instituto de Ciencias del Mar y Limnología, Universidad Nacional Autónoma de México, Unidad Académica \\ Procesos Oceánicos y Costeros, Circuito Exterior s/n, Ciudad Universitaria, 04510 México DF. \\ ${ }^{3}$ Universidad Nacional Autónoma de México, Unidad Académica Mazatlán, Calz. J. Montes Camarena s/n, \\ Col. Playa Sur, 82040 Mazatlán, Sinaloa, México. \\ ${ }^{4}$ Facultad de Ciencia y Tecnología, Universidad del País Vasco UPV/EHU, Apartado 644, 48080 Bilbao, \\ España. \\ ${ }^{5}$ Departamento de Geología, Facultad de Ingeniería, Universidad Nacional Autónoma de México, Ciudad \\ Universitaria, 04510 México DF. \\ ${ }^{6}$ Posgrado en Ciencias del Mar y Limnología, Instituto de Ciencias del Mar y Limnología, Universidad \\ Nacional Autónoma de México, Unidad Académica Mazatlán, Calz. J. Montes Camarena s/n, Col. Playa Sur, \\ 82040 Mazatlán, Sinaloa, México. \\ * Corresponding author. Email: machain@cmarl.unam.mx
}

\begin{abstract}
The geochemical, mineralogical, and micropaleontological (Foraminifera, Ostracoda, Bacillariophyta) spatial and temporal variations in marshland sediments from the Jiquilisco Bay Biosphere Reserve, El Salvador, are described. The sedimentary characteristics of two marsh sites reveal contrasting sedimentary environments: site Los Cedrones depicts a high energy environment with sandy sediments, low organic matter content, and no microfossils, while site El Gimidor represents a lower energy environment with muddy sediments rich in organic matter and more abundant and diverse microfossils. ${ }^{210} \mathrm{~Pb}$-dated sedimentary cores showed changes over time (last 100 years) in the mineral and elemental composition, as well as in the accumulation rates, suggesting changes in the type and magnitude of sediments delivered to the sites. Sediment accumulation rates were similar at both sites, ranging from $1.2 \pm 0.9$ to $3.4 \pm 0.5 \mathrm{~mm}^{-1}$ at Los Cedrones and from $0.8 \pm 0.2$ to $4.0 \pm 0.5 \mathrm{~mm} \mathrm{yr}^{-1}$ at El Gimidor. Even though both marshes are located $13 \mathrm{~km}$ apart, and depict different sedimentary environments, elemental composition, and microfossil assemblages, both sedimentary records show the influence of hydrological changes, probably due to the damming of the Lempa River and the sea-level increase during the last 100 years.
\end{abstract}

Key words: marshes, ${ }^{210} \mathrm{~Pb}$, microfossils, sea-level changes, Jiquilisco Bay Complex.

RESUMEN. Este trabajo describe la variación espacial y temporal de las características geoquímicas, mineralógicas y micropaleontológicas (foraminíferos, ostrácodos y diatomeas) de sedimentos de marismas en la Reserva de la Biósfera Bahía de Jiquilisco, El Salvador. Las características de los sedimentos de las marismas estudiadas refieren ambientes sedimentarios contrastantes: el sitio Los Cedrones corresponde a un ambiente arenoso, pobre en materia orgánica, sin microfósiles (foraminíferos, ostrácodos, diatomeas) e influenciado por una hidrodinámica de alto nivel de energía, mientras que el sitio El Gimidor representa un ambiente lodoso, léntico, rico en materia orgánica y con mayor abundancia y diversidad micropaleontológica. Los núcleos sedimentarios, fechados con ${ }^{210} \mathrm{~Pb}$, mostraron cambios temporales (últimos 100 años) conspicuos en la composición mineralógica y elemental, así como en las tasas de acumulación, que sugieren modificaciones en el tipo de fuente y la magnitud del aporte sedimentario. Los intervalos de las tasas de acumulación sedimentaria observados en ambos sitios de muestreo fueron comparables: de $1.2 \pm 0.9$ a $3.4 \pm 0.5 \mathrm{~mm}$ año ${ }^{-1}$ en Los Cedrones y de $0.8 \pm 0.2$ a $4.0 \pm 0.5 \mathrm{~mm}$ año ${ }^{-1}$ en El Gimidor. Aun cuando existe una distancia de $13 \mathrm{~km}$ entre las dos marismas estudiadas, y pese a las marcadas diferencias en términos de tipo de ambiente sedimentario, composición elemental y agrupación de especies de microfósiles, los dos registros sedimentarios mostraron la huella de cambios hidrológicos, probablemente relacionados con el represamiento del río Lempa y el aumento del nivel marino en la zona durante los últimos 100 años.

Palabras clave: marismas, ${ }^{210} \mathrm{~Pb}$, microfósiles, cambio de nivel del mar, Complejo Bahía de Jiquilisco. 


\section{INTRODUCTION}

One of the most important effects of global change on coastal areas is rising sea level, caused by the melting of polar ice caps and the thermal expansion of seawater due to the warming of the atmosphere and oceans (Church et al. 2013). Sea-level rise poses a serious environmental problem (higher-order impact) for society due to, among other factors, the loss of habitable land and economic infrastructure in the coastal zone, and the salinization of land and aquifers. Nonetheless, the lack of long-term environmental data hampers the development of protection and mitigation measures for fragile ecosystems, such as coastal ecosystems.

The study of sediment cores allows the historical reconstruction of environmental changes, for which it is necessary to have continuous sediment deposition over time and a reliable dating method. With the ${ }^{210} \mathrm{~Pb}$ dating method it is possible to determine discontinuities in the sediment profile and develop geochronologies of 100-150 years, and it is thus widely used to study the trends of climate change impacts, such as heavy-metal pollution or increase in sediment accumulation rates in aquatic systems (e.g., Ruiz-Fernández and Hillaire-Marcel 2009). Moreover, the accretion rates obtained by ${ }^{210} \mathrm{~Pb}$ dating can be useful in determining the magnitude of sea-level change (e.g., Lynch et al. 1989), since the rate of accumulation of some coastal sediment deposits, especially in high marshlands, is controlled by the balance between the input and erosion of the material due to tidal action; therefore, accretion rates follow the rhythm of sea-level rise (Smoak et al. 2013).

Changes in the environmental conditions of aquatic systems have an effect on their morphology, geochemistry, and the community structure of certain organisms. Hence, the analysis of mineralogical characteristics, elemental composition, and micropaleontological assemblages (e.g., foraminifera, ostracods, and diatoms) in sediment cores is widely used to determine past changes to ecosystems, particularly in relation to sea level (Cearreta et al. 2003, Kemp et al. 2013).

Mineralogical studies allow us to infer the source areas of coastal sediments and define the energy characteristics of the depositional environment. For example, coastal sediments rich in quartz and heavy metals are associated with highenergy environments (e.g., beaches and tidal channels), whereas the presence of evaporites and sandy-mud soil rich in organic matter is indicative of low-energy lentic bodies (Folk 1980). Magnetic susceptibility can be useful to identify changes in the sediment sources, under the assumption that the magnetic minerals (e.g., iron oxides and titanium) in sediments are detrital in origin and that the variations in their supply are due to environmental alterations like soil erosion (e.g., Ruiz-Fernández et al. 2005) or changes in sea level (e.g., Ellwood et al. 2000), among others.

The elemental composition of coastal sediments can help to identify the transition between environments (e.g., terrigenous versus marine influence associated with sea-level rise)

\section{INTRODUCCIÓN}

Uno de los impactos más importantes del cambio global sobre las zonas costeras es la elevación del nivel del mar, producto del deshielo de los casquetes polares y la expansión térmica del agua oceánica debido al calentamiento de la atmósfera y los océanos (Church et al. 2013). La elevación del nivel del mar es un problema ambiental de alto impacto para la sociedad debido, entre otros factores, a la pérdida de terrenos habitables e infraestructura económica en la zona costera, así como la salinización de los mantos acuíferos y terrenos. No obstante, la escasez de datos ambientales de largo plazo entorpece el desarrollo de medidas de protección y/o mitigación de ecosistemas frágiles, tales como los ecosistemas costeros.

El estudio de núcleos sedimentarios permite la reconstrucción histórica de cambios ambientales, para lo cual se requiere que exista un depósito de sedimentos continuo en el tiempo y se disponga de un fechado confiable. El método de fechado con ${ }^{210} \mathrm{~Pb}$ permite reconocer discontinuidades en el perfil sedimentario y desarrollar geocronologías de hasta 100-150 años, por lo que es ampliamente utilizado para el estudio de las tendencias de los impactos del cambio global, tales como la contaminación por metales pesados o el incremento de las tasas de acumulación sedimentaria en sistemas acuáticos (e.g., Ruiz-Fernández y Hillaire-Marcel 2009). Adicionalmente, se ha demostrado que las tasas de acreción determinadas por el método de ${ }^{210} \mathrm{~Pb}$ pueden ser útiles para determinar la magnitud del cambio del nivel marino (e.g., Lynch et al. 1989), ya que la velocidad de acumulación de algunos depósitos sedimentarios costeros, especialmente en las marismas altas, está controlada por el balance entre el aporte y la erosión del material debido a la acción de las mareas y, por lo tanto, las tasas de acreción siguen el ritmo de la elevación del nivel del mar (Smoak et al. 2013).

Los cambios en las condiciones ambientales de los sistemas acuáticos repercuten en la modificación de su morfología, su geoquímica y las estructuras comunitarias de ciertos organismos, razón por la cual el análisis de las características mineralógicas, la composición elemental y las asociaciones micropaleontológicas (e.g., foraminíferos, ostrácodos y diatomeas) en núcleos sedimentarios es ampliamente utilizado para evidenciar cambios en los ecosistemas del pasado, en particular en relación al nivel del mar (Cearreta et al. 2003, Kemp et al. 2013).

Los estudios mineralógicos permiten inferir las áreas fuente de los sedimentos costeros y dilucidar las características de energía del ambiente de depósito. Por ejemplo, sedimentos costeros ricos en cuarzo y minerales pesados se asocian con ambientes de alta energía (e.g., playas y canales de mareas), mientras que la presencia de evaporitas y materiales lodo-arenosos ricos en materia orgánica es indicativo de cuerpos lénticos de baja energía (Folk 1980). La susceptibilidad magnética puede ser útil para identificar cambios en las fuentes sedimentarias, bajo la suposición de que los 
by examining the temporal record of the concentration of enriched elements in seawater (e.g., $\mathrm{Cl}, \mathrm{Na}$, and $\mathrm{Br}$; Sadiq 1992) and the elements traditionally used as proxies of terrigenous inputs (e.g., Al, Ti, Rb, and Zr; Pattan et al. 2005).

This paper reports the first data on the spatial and temporal distribution of the geochemical, mineralogical, and micropaleontological composition of surface sediments and of ${ }^{210} \mathrm{~Pb}$-dated sediment cores collected from the Jiquilisco Bay Complex (JBC) in El Salvador, in order to obtain evidence of the hydrological changes (e.g., damming of the Lempa River and sea-level changes) that have occurred over the past 100 years.

\section{MATERIALS AND METHODS}

\section{Study area}

The JBC is located in southeastern El Salvador (fig. 1), and has been recognized as a Ramsar site since 2005 and as a UNESCO biosphere reserve since 2007. It has the largest expanse of perennial wetlands in the country, with brackish-water ecosystems and large areas $(\sim 18,700 \mathrm{ha})$ of mangrove forests, including the species Rhyzophora mangle, Rhyzophora racemosa, Rhizophora harrisonii, Avicennia germinans, Avicennia bicolor, Conocarpus erecta, and Laguncularia racemosa, as well as the freshwater mangrove Bravaisia integerrima. The JBC is an important nesting site for coastal seabirds and an important fishing area. The climate in the area is tropical savanna, with a mean annual temperature of $28^{\circ} \mathrm{C}$ and a maximum of $36^{\circ} \mathrm{C}$. Annual rainfall ranges from 1600 to $2000 \mathrm{~mm}$, mainly from May to October, and mean annual evapotranspiration is $1944 \mathrm{~mm}$ (MARN/ AECI 2004).

The JBC is located between two rivers. The Lempa River discharges into the Pacific Ocean in the westernmost part of the complex and has an average flow of $175 \mathrm{~m}^{3} \mathrm{~s}^{-1}$. Three hydroelectric dams (Cerrón Grande, 5 de Noviembre, and 15 de Septiembre), built between 1954 and 1983 along its course, are located between 49 and $99 \mathrm{~km}$ from the study area. The Grande de San Miguel River discharges on the mideastern side of the JBC and has an average flow of $24 \mathrm{~m}^{3} \mathrm{~s}^{-1}$ (SNET 2004).

Most of El Salvador's territory is covered by volcanic rock. The stratigraphic succession in the study area consists of Quaternary alluvial deposits covering volcanic strata (Holocene-Pleistocene) of basaltic, andesitic, and dacitic composition (MARN 2013).

\section{Survey}

The sediment cores were collected manually (push core) in August 2012, using PVC pipes (10 cm diameter), from two marsh sites (fig. 1): Los Cedrones (core ELS-I, $44 \mathrm{~cm} \mathrm{long)}$ and El Gimidor (core ELS-II, $50 \mathrm{~cm}$ long). The sampling sites are located in flat areas, at a higher elevation than the minerales magnéticos (e.g., óxidos de hierro y titanio) de los sedimentos tienen un origen detrítico y que las variaciones de su suministro pueden resultar, entre otros, de alteraciones ambientales como la erosión de suelos (e.g., Ruiz-Fernández et al. 2005) o cambios en el nivel del mar (e.g., Ellwood et al. 2000).

La composición elemental de sedimentos costeros puede ayudar a identificar la transición de ambientes (e.g., influencia terrígena versus marina, debido a la elevación del nivel del mar) mediante la evaluación del registro temporal de la concentración de elementos enriquecidos en el agua de mar (e.g., Cl, Na y Br; Sadiq 1992) y los elementos tradicionalmente usados como indicadores (proxies) del aporte de sedimentos terrígenos (e.g., Al, Ti, Rb, Zr; Pattan et al. 2005).

En el presente trabajo se reportan los primeros datos de la distribución espacial y temporal de la composición geoquímica, mineralógica y micropaleontológica de sedimentos superficiales y de núcleos sedimentarios fechados con ${ }^{210} \mathrm{~Pb}$, recolectados en el Complejo Bahía de Jiquilisco (CBJ) en El Salvador, con el objetivo de identificar las evidencias de los cambios hidrológicos (e.g., represamiento del río Lempa y cambios en el nivel del mar) ocurridos durante los últimos 100 años.

\section{MATERIALES Y MÉTODOS}

\section{Área de estudio}

El CBJ se ubica al sureste de El Salvador (fig. 1), y ha sido reconocido como sitio RAMSAR desde 2005 y como reserva de la biósfera de la UNESCO desde 2007. Posee la mayor extensión perenne de humedales en el país, con ecosistemas de agua salobre y grandes extensiones de bosque salado $(\sim 18,700 \mathrm{ha})$, incluyendo las especies de mangle Rhyzophora mangle, Rhyzophora racemosa, Rhizophora harrisonii, Avicennia germinans, Avicennia bicolor, Conocarpus erecta y Laguncularia racemosa, así como el mangle de agua dulce Bravaisia integerrima. El CBJ es una importante zona de anidación para especies de aves marinocosteras y de producción pesquera. El clima en el CBJ es de sabana tropical-caliente, con una temperatura promedio anual de $28^{\circ} \mathrm{C}$ y un máximo de $36^{\circ} \mathrm{C}$. La precipitación anual varía entre 1600 y $2000 \mathrm{~mm}$, principalmente de mayo a octubre, y la evapotranspiración media anual es de 1944 mm (MARN/ AECI 2004).

El CBJ se encuentra ubicado entre dos ríos. El río Lempa, que descarga sus aguas al océano Pacífico en el extremo oeste de CBJ, tiene un caudal medio de $175 \mathrm{~m}^{3} \mathrm{~s}^{-1} \mathrm{y}$ a lo largo de su curso, cuenta con tres presas hidroeléctricas construidas entre 1954 y 1983 (Cerrón Grande, 5 de Noviembre y 15 de Septiembre), ubicadas entre 49 y $99 \mathrm{~km}$ de la zona de estudio. El río Grande San Miguel, que descarga en la parte mediaoriental de CBJ, tiene un caudal medio de $24 \mathrm{~m}^{3} \mathrm{~s}^{-1}$ (SNET 2004).

La mayor parte del territorio de El Salvador está cubierto por rocas de origen volcánico. La sucesión estratigráfica en la 


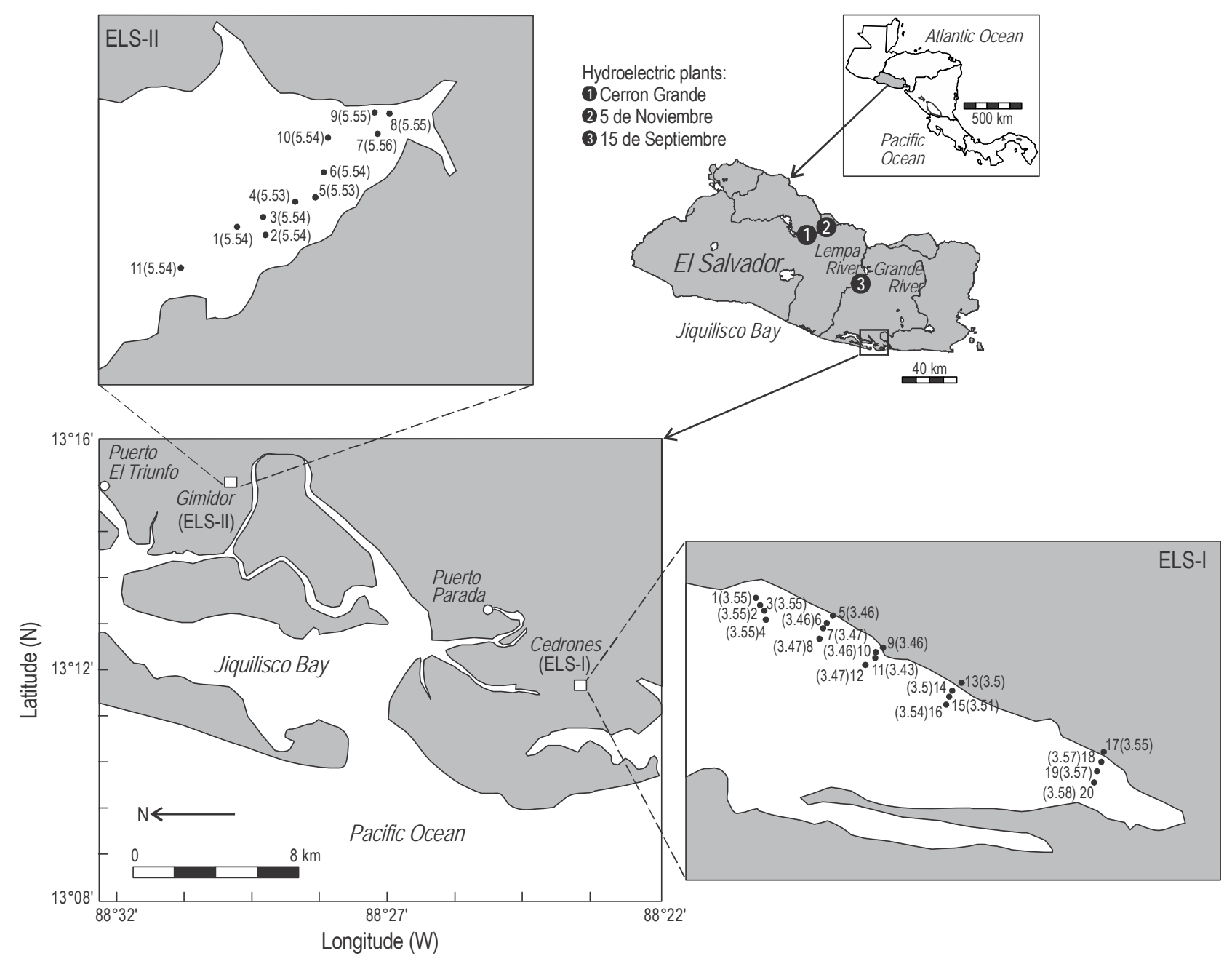

Figure 1. Jiquilisco Bay Complex, El Salvador. The locations of the sampling stations at the two sampling sites, Los Cedrones (ELS-I) and El Gimidor (ELS-II), are shown and their elevations (in meters) are given in parentheses.

Figura 1. Complejo Bahía de Jiquilisco, El Salvador. Se indican las estaciones de muestreo en las dos marismas estudiadas, Los Cedrones (ELS-I) y El Gimidor (ELS-II), y entre paréntesis las alturas (en metros) de cada estación.

mangrove fringe. They are intermittently flooded (during high tide) and are not affected by human activities or livestock grazing. The sediment cores were split longitudinally and $1-\mathrm{cm}$-thick sections were cut.

Surface sediment samples were also collected at each site using plastic spatulas and a PVC ring $(10 \mathrm{~cm}$ diameter, $1 \mathrm{~cm}$ deep, $\sim 78 \mathrm{~cm}^{3}$ of sediment). The relative height of each sampling point was determined in relation to the surface of the previously collected core (resolution of $1 \mathrm{~mm}$ ), using a Sokkia SET630RK/D22845 total station and a Trimble GPS Pathfinder Pro XT (fig. 1).

The sediment samples were oven-dried at a temperature of $<60{ }^{\circ} \mathrm{C}$ until constant weight. Aliquots were taken for the analysis of grain size and microfossils, and the rest was ground in a porcelain mortar and stored in polyethylene bags until further analysis. zona de CBJ está compuesta por aluviones cuaternarios que recubren a estratos volcánicos (Holoceno-Pleistoceno) de composición basáltica, andesítica y dacítica (MARN 2013).

\section{Muestreo}

Los núcleos sedimentarios se recolectaron manualmente (push core) en agosto de 2012, mediante el uso de tubos de $\mathrm{PVC}$ de $10 \mathrm{~cm}$ de diámetro, en dos zonas de marismas (fig. 1): Los Cedrones (núcleo ELS-I, $44 \mathrm{~cm}$ de longitud) y El Gimidor (núcleo ELS-II, $50 \mathrm{~cm}$ ). Las zonas de muestreo se ubicaron en terrenos planos, más elevados que la franja de manglar, inundables de manera intermitente (durante la marea alta), y alejados de la intervención humana y el acceso al ganado. Los núcleos se abrieron longitudinalmente y se cortaron secciones de $1 \mathrm{~cm}$ de espesor. 


\section{Laboratory analyses}

Analysis of elemental composition (Al, Fe, Mn, Si, Ti, $\mathrm{Rb}, \mathrm{Zr}, \mathrm{Br}, \mathrm{Cl}$ ) was performed on sediment samples compressed manually by a Teflon roller in an X-ray fluorescence (XRF) spectrometer (Spectrolab Xepos-3) under He atmosphere. Magnetic susceptibility (MS) was determined using a Bartington MS2 analyzer coupled to a simple frequency MSG2 sensor. Grain-size distribution was determined using a Malvern Mastersizer 2000 laser diffraction particle size analyzer. Organic matter and carbonate contents were estimated by determining loss on ignition at 550 and $950{ }^{\circ} \mathrm{C}\left(\mathrm{PPI}_{550}\right.$ and $\mathrm{PPI}_{950}$ ), respectively. Sediments were dated by determining the activity of ${ }^{210} \mathrm{~Pb}$ through its radioactive descendant ${ }^{210} \mathrm{Po}$ by alpha spectrometry (Ortec Ametek 576A spectrometer), according to the method described by Ruiz-Fernández and Hillaire-Marcel (2009); the results are expressed in years of the common era. The quality control of the analyses included the evaluation of analytical blanks, the analysis of replicates $(n=6)$ to assess the precision of the analyses, and the analysis of the following reference materials to determine the accuracy of the methods: IAEA-158, IAEA-405, and IAEA433 for XRF; IAEA-300 for ${ }^{210} \mathrm{~Pb}$; Bartington G-039 for MS; and Malvern QAS3002 for grain size. The results were in the range of the certified values for the reference materials $(1 \sigma)$. The coefficients of variation were $<8 \%$ for the XRF, $\mathrm{PPI}_{550}$, and $\mathrm{PPI}_{950}$ analyses; $<5 \%$ for ${ }^{210} \mathrm{~Pb}$ and grain size; and $<3 \%$ for MS.

The samples for the analysis of foraminifera, ostracods, and diatoms were washed over a $63-\mu \mathrm{m}$ sieve, dried at room temperature, and stained with Rose Bengal (Murray 2006). The dry residues were examined under a stereoscopic microscope. The extracted organisms were determined taxonomically and were quantified by grouping the live individuals (stained) and dead individuals (unstained) in a total assemblage due to the small number of specimens. The diatoms present in this fraction were quantified. For the mineralogical analysis, thin films of the sandy sediment fraction were prepared and the grains were counted by petrographic microscopy (Potter 1978).

\section{RESULTS}

\section{Surface sediments}

\section{Site ELS-I (Los Cedrones)}

The surface sediments from site ELS-I were predominantly sandy $(68-83 \%)$, with low concentrations of organic matter $\left(\mathrm{PPI}_{550} \leq 1.2 \%\right)$ and carbonates $\left(\mathrm{PPI}_{950} 1-6 \%\right.$, except for $13 \%$ at station 1 ), and an almost homogeneous elemental composition (fig. 2). The sandy fraction was mainly composed of quartz (40-55\%), plagioclase (10-20\%), heavy minerales (5-35\%), and volcanic (5-30\%) and sedimentary $(5-10 \%)$ rock fragments. The heavy minerals were more
En cada sitio de muestreo también se recolectaron muestras de sedimento superficial con la ayuda de espátulas de plástico y un aro de PVC $(10 \mathrm{~cm}$ de diámetro, $1 \mathrm{~cm}$ de profundidad, $\sim 78 \mathrm{~cm}^{3}$ de sedimento). Se determinó la altura relativa de cada punto de muestreo con relación a la superficie del núcleo previamente recolectado, con una resolución de $1 \mathrm{~mm}$, mediante el uso de una estación total Sokkia, modelo SET630RK/D22845, y un GPS Trimble, modelo Pro XT (fig. 1).

Los sedimentos recolectados se secaron hasta un peso constante en estufa a una temperatura inferior a $60^{\circ} \mathrm{C}$. Se tomaron alícuotas para el análisis de tamaño de grano y microfósiles, y el resto se molió en mortero de porcelana y se conservó en bolsas de polietileno hasta su análisis.

\section{Análisis de laboratorio}

El análisis de la composición elemental (Al, Fe, Mn, Si, $\mathrm{Ti}, \mathrm{Rb}, \mathrm{Zr}, \mathrm{Br}, \mathrm{Cl}$ ) se realizó en muestras de sedimento comprimidas manualmente con un apisonador de teflón, en un espectrómetro de fluorescencia de rayos X (XRF, por sus siglas en inglés, Xepos-3 de Spectrolab) en atmósfera de He. La susceptibilidad magnética (SM) se determinó con un analizador Bartington MS2 acoplado a un sensor de frecuencia simple MSG2. La distribución de tamaño de grano se determinó por difracción de rayo láser con un analizador Malvern Mastersizer 2000. La concentración de materia orgánica y de carbonatos se estimó a través de la determinación de las pérdidas por ignición a 550 y $950{ }^{\circ} \mathrm{C}\left(\mathrm{PPI}_{550}\right.$ y $\left.\mathrm{PPI}_{950}\right)$, respectivamente. Para el fechado de los sedimentos, se determinó la actividad de ${ }^{210} \mathrm{~Pb}$ a través de su descendiente radioactivo ${ }^{210}$ Po por espectrometría alfa (Ortec Ametek, modelo 576A) según el método descrito por Ruiz-Fernández y Hillaire-Marcel (2009); los resultados se expresan en años de la era común. El control de calidad de los análisis realizados incluyó la determinación de blancos analíticos, el análisis de réplicas $(n=6)$ para evaluar la precisión de los análisis, y el análisis de materiales de referencia para determinar la exactitud de los métodos. Los resultados del análisis de materiales de referencia IAEA-158, IAEA-405 y IAEA-433 para XRF, IAEA-300 para ${ }^{210} \mathrm{~Pb}$, Bartington G-039 para SM, y Malvern QAS3002 para tamaño de grano, se encontraron en el intervalo de sus valores certificados $(1 \sigma)$. Los coeficientes de variación fueron $<8 \%$ para los análisis de XRF, $\operatorname{PPI}_{550} \mathrm{y}$ $\mathrm{PPI}_{950} ;<5 \%$ para ${ }^{210} \mathrm{~Pb}$ y tamaño de grano; $\mathrm{y}<3 \%$ para $\mathrm{SM}$.

Las muestras para foraminíferos, ostrácodos y diatomeas se lavaron con agua corriente a través de un tamiz de $63 \mu \mathrm{m}$, se secaron a temperatura ambiente y se tiñeron con Rosa de Bengala (Murray 2006). Los residuos secos se revisaron con un microscopio estereoscópico. Los organismos extraídos se determinaron taxonómicamente y se cuantificaron agrupando los individuos vivos (teñidos) y muertos (no teñidos) en una asociación total debido al reducido número de ejemplares presentes. Se cuantificaron las diatomeas presentes en esta fracción. Para el análisis mineralógico, se realizaron láminas 
abundant in the central part of the marsh (stations 11 to 16). Foraminifera, ostracods, and diatoms were not found in any of the samples analyzed.

Site ELS-II (El Gimidor)

The sediments from site ELS-II were predominantly muddy (59-86\%), with a high percentage of organic matter (PPI 550 16-19\%) and low carbonate content ( $\mathrm{PPI}_{950} 3-7 \%$ ). The sandy fraction was mainly composed of plant remnants and lithics (5-20\%), mainly plagioclase and volcanic lithics. All the samples had a similar elemental composition (fig. 2), and they had a higher concentration of elements considered indicators of marine influence (i.e., $\mathrm{Na}, \mathrm{Cl}, \mathrm{Br}$ ) and a lower concentration of terrigenous materials $(\mathrm{Rb}, \mathrm{Al}, \mathrm{Si}, \mathrm{K}, \mathrm{Ti}, \mathrm{Zr})$ than the ELS-I samples.

Foraminifera, ostracods, diatoms, and some gastropods were found in the ELS-II sediments (table 1), but due to their low diversity and abundance it was not possible to delimit the subenvironments in the study area. Eight species of foraminifera were found, two of marine origin, Nonionella sp. and Neogloboquadrina dutertrei (d'Orbigny), probably introduced via tidal waters. Numerous fragments of agglutinated foraminifera were also observed. The most abundant species were (in decreasing order) Arenoparella mexicana (Kornfeld), Cribroelphidium gunteri (Cole), Ammotium salsum (Cushman and Brönnimann), and Ammonia tepida (Cushman). Only one specimen of both Textularia sp. and Trochamina inflata (Montagu) was recorded. All these species tolerate a wide range of salinities and are characteristic of coastal lagoons, estuaries, and mangrove forests (Murray 2006). The ostracod populations also showed low diversity and abundance. The most abundant species were (in decreasing order) Perissocytheridea sp., Perissocytheridea cf. P. meyerabichi (Hartmann), Cyprideis castus Benson, and two specimens of Loxoconcha? magnipustulosa Swain and Gilby. These organisms have been found in brackish waters, in a wide range of salinities, in different areas of the American Pacific (e.g., Hartmann 1956, Sandberg 1966, Swain and Gilby 1967, Phleger 1967). Few planktonic diatoms of marine origin were found and only their presence was recorded since they may have been transported by water birds.

\section{${ }^{210} \mathrm{~Pb}$-dated sediment cores}

The profiles of ${ }^{210} \mathrm{~Pb}$ activity in the ELS-I and ELS-II sediment cores (fig. 3) showed a decreasing trend with depth, which indicates continuous sediment deposition. The activity values for ELS-I (coarser sediment) were much lower than for ELS-II (finer sediment). The chronologies were calculated using the constant flux model (Sanchez-Cabeza and Ruiz-Fernández 2012), and the uncertainties were estimated by the Monte Carlo method with 30,000 simulations delgadas de muestras de la fracción arenosa de los sedimentos y se hicieron conteos de granos de diferentes campos con un microscopio petrográfico (Potter 1978).

\section{RESUltados}

\section{Sedimentos superficiales}

\section{Sitio ELS-I (Los Cedrones)}

Los sedimentos superficiales del sitio ELS-I fueron predominantemente arenosos (68-83\%), con concentraciones bajas de materia orgánica $\left(\mathrm{PPI}_{550} \leq 1.2 \%\right)$ y de carbonatos ( $\mathrm{PPI}_{950} 1-6 \%$, excepto en la estación 1, con 13\%), y una composición elemental casi homogénea (fig. 2). La fracción arenosa estuvo compuesta en su mayoría por cuarzo (40-55\%), plagioclasas (10-20\%), minerales pesados (5-35\%) y fragmentos de rocas volcánicas $(5-30 \%)$ y sedimentarias (5-10\%). Los minerales pesados fueron más abundantes en la parte central de la marisma (estaciones 11 a 16). No se encontraron foraminíferos, ostrácodos ni diatomeas en ninguna de las muestras superficiales analizadas.

\section{Sitio ELS-II (El Gimidor)}

Los sedimentos del sitio ELS-II fueron predominantemente limosos (59-86\%), con altos porcentajes de materia orgánica $\left(\mathrm{PPI}_{550} 16-19 \%\right)$ y bajo porcentaje de carbonatos ( $\mathrm{PPI}_{950} 3-7 \%$ ). La fracción arenosa de los sedimentos estuvo compuesta principalmente por restos vegetales y un 5-20\% de líticos, principalmente plagioclasas y líticos volcánicos. La composición elemental fue muy similar entre las muestras (fig. 2), las cuales tuvieron mayor concentración de elementos indicadores de influencia marina (i.e., $\mathrm{Na}, \mathrm{Cl}, \mathrm{Br}$ ) y menor de terrígenos ( $\mathrm{Rb}, \mathrm{Al}, \mathrm{Si}, \mathrm{K}, \mathrm{Ti}, \mathrm{Zr})$ que las observadas en el sitio ELS-I (Los Cedrones).

Aunque se encontraron foraminíferos, ostrácodos, diatomeas y algunos gasterópodos (tabla 1), debido a su baja diversidad y abundancia no fue posible la delimitación de subambientes en la zona de estudio. Se encontraron ocho especies de foraminíferos, dos de origen marino, Nonionella sp. y Neogloboquadrina dutertrei (d'Orbigny), probablemente introducidas vía los canales de marea, y numerosos fragmentos de foraminíferos aglutinados. Las especies más abundantes en orden decreciente fueron Arenoparella mexicana (Kornfeld), Cribroelphidium gunteri (Cole), Ammotium salsum (Cushman y Brönnimann) y Ammonia tepida (Cushman). Textularia sp. y Trochamina inflata (Montagu) sólo presentaron un ejemplar cada una. Todas estas especies toleran amplios intervalos de salinidad y son características de lagunas costeras, estuarios y manglares (Murray 2006). Las poblaciones de ostrácodos presentaron también baja diversidad y abundancia. En orden decreciente, las especies más abundantes fueron Perissocytheridea sp., Perissocytheridea cf. P. meyerabichi (Hartmann), Cyprideis 

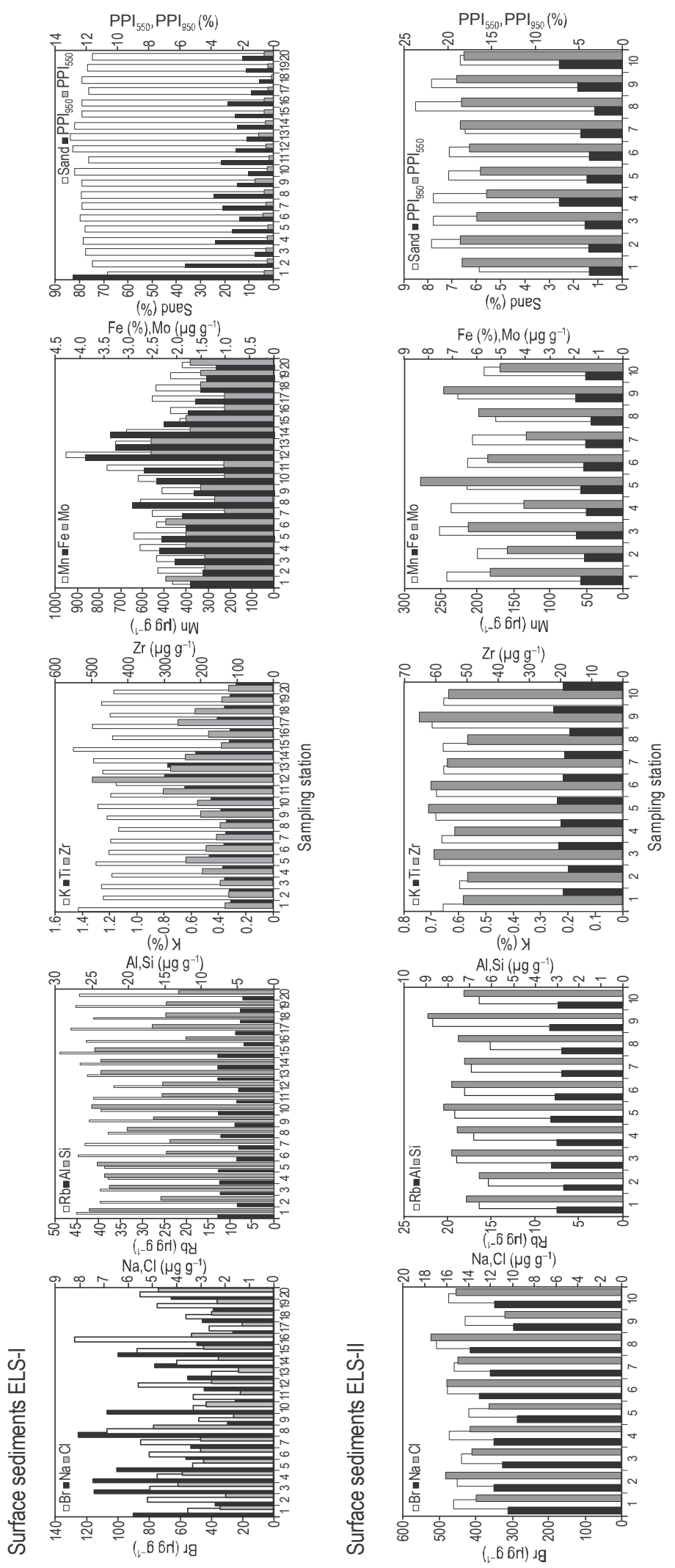

Figure 2. Elemental composition, magnetic susceptibility, grain size, and percentages of $\mathrm{PPI}_{550}$ (organic matter) and $\mathrm{PPI}_{950}(\mathrm{carbonates})$ of the ELS-I and ELS-II surface sediments.

Figura 2. Composición elemental, susceptibilidad magnética, tamaño de grano y porcentajes de $\mathrm{PPI}_{550}\left(\mathrm{materia}\right.$ orgánica) y $\mathrm{PPI}_{950}$ (carbonatos) en los sedimentos superficiales de ELS-I y ELS-II. 
Table 1. Micropaleontological composition (number of organisms) of the ELS-II surface sediments. The asterisk indicates presence.

Tabla 1. Composición micropaleontológica (número de organismos) de los sedimentos superficiales de ELS-II. El asterisco indica presencia.

\begin{tabular}{|c|c|c|c|c|c|c|c|c|c|c|c|}
\hline Species & \multicolumn{11}{|c|}{ Sampling station } \\
\hline \multicolumn{12}{|l|}{ Benthic foraminifera } \\
\hline Ammonia tepida & & & & & & 4 & 1 & & & & \\
\hline Ammotium salsum & & & & 1 & 1 & 3 & 2 & 2 & & & \\
\hline Arenoparella mexicana & & & 1 & 4 & 1 & 2 & 4 & 2 & 15 & & 2 \\
\hline Nonionella (fragments) & & & 1 & & & & & & & & \\
\hline Textularia sp. & & & 1 & & & & & & & & \\
\hline Ammotium + Ammobaculites (fragments) & & & 1 & 3 & & 30 & 2 & 8 & 47 & 4 & 7 \\
\hline Trochamina inflata & & & & & & & 1 & & & & \\
\hline Cyprideis bensoni & & 3 & & 1 & & 4 & 1 & 4 & & 2 & 2 \\
\hline Loxoconcha? Magnipustulosa & & 1 & & 1 & & & & & & & \\
\hline Perissocytheridea cf. P. meyerabichi & & 17 & 3 & 3 & 1 & 5 & 2 & 1 & & 1 & \\
\hline Perissocytheridea sp. 1 & & 41 & & 7 & 4 & 4 & 4 & 4 & & & 5 \\
\hline Diatoms & & & $*$ & * & & * & $*$ & & & & $*$ \\
\hline Gastropods & $*$ & $*$ & & * & & & & & & $*$ & $*$ \\
\hline
\end{tabular}

(Sanchez-Cabeza et al. 2014). The oldest age estimated for ELS-I was $105 \pm 8$ years (22-23 cm section) and for ELS-II, $163 \pm 7$ years (32-33 cm section).

The mass accumulation rate (MAR) and sediment accumulation rate (SAR) showed notable and coincident variations over time in both cores, and similar value ranges were obtained for both cores (fig. 3). In ELS-I, MAR increased from $0.18 \pm 0.15 \mathrm{~g} \mathrm{~cm}^{-2} \mathrm{yr}^{-1}$ in the $21-22 \mathrm{~cm}$ section (year 1912 ) to $0.36 \pm 0.05 \mathrm{~g} \mathrm{~cm}^{-2} \mathrm{yr}^{-1}$ at the surface (year 2011), and there were two pronounced peaks, in $1944(15-16 \mathrm{~cm}$ section) and 2002 (3-4 cm section). SAR increased from a minimum value of $1.2 \pm 0.9 \mathrm{~mm} \mathrm{yr}^{-1}$ in the $20-21 \mathrm{~cm}$ section (year 1920) to a maximum of $3.4 \pm 0.5 \mathrm{~mm} \mathrm{yr}^{-1}$ at the surface. There was a clear peak in $1944\left(3.0 \pm 0.2 \mathrm{~mm} \mathrm{yr}^{-1}\right)$ and an almost linear increase after 1971.

In ELS-II, MAR increased from $0.04 \pm 0.01 \mathrm{~g} \mathrm{~cm}^{-2} \mathrm{yr}^{-1}$ (32-33 cm section) to $0.15 \pm 0.01 \mathrm{~g} \mathrm{~cm}^{-2} \mathrm{yr}^{-1}$ at the core surface (year 2011). Similar to ELS-I, MAR showed a general increasing trend towards the surface, with a pronounced peak in 1944 (15-16 cm section). SAR increased from a minimum value of $0.8 \pm 0.2 \mathrm{~mm} \mathrm{yr}^{-1}$ in 1856 to a subsurface maximum of $4.0 \pm 0.5 \mathrm{~mm} \mathrm{yr}^{-1}$ in 1942, after which it decreased to $1.6 \pm 0.2 \mathrm{~mm} \mathrm{yr}^{-1}$ in 1972 and then progressively increased again to $4.0 \pm 0.4 \mathrm{~mm} \mathrm{yr}^{-1}$ in 2009 . castus Benson y dos ejemplares de Loxoconcha? magnipustulosa Swain y Gilby. Estos organismos se han encontrado en aguas salobres, en un amplio intervalo de salinidad, en diversas partes del Pacífico americano (e.g., Hartmann 1956, Sandberg 1966, Swain y Gilby 1967, Phleger 1967). Se encontraron escasas diatomeas planctónicas de origen marino y sólo se registró su presencia, pues pueden haber sido transportadas por aves acuáticas.

\section{Núcleos sedimentarios fechados con ${ }^{210} \mathbf{P b}$}

Los perfiles de las actividades de ${ }^{210} \mathrm{~Pb}$ de los núcleos ELS-I y ELS-II (fig. 3) exhibieron una tendencia decreciente con la profundidad, lo cual indica un depósito continuo de sedimentos, aunque los valores de actividad del núcleo ELS-I (sedimento más arenoso) fueron mucho menores que los del núcleo ELS-II (sedimento más fino). Las cronologías se calcularon utilizando el modelo de flujo constante (SanchezCabeza y Ruiz-Fernández 2012) y las incertidumbres se estimaron utilizando el método de Monte Carlo con 30,000 simulaciones (Sanchez-Cabeza et al. 2014). La edad más antigua estimada para el núcleo ELS-I fue de $105 \pm 8$ años (sección 22-23 cm) y de $163 \pm 7$ años para el núcleo ELS-II $(32-33 \mathrm{~cm})$. 

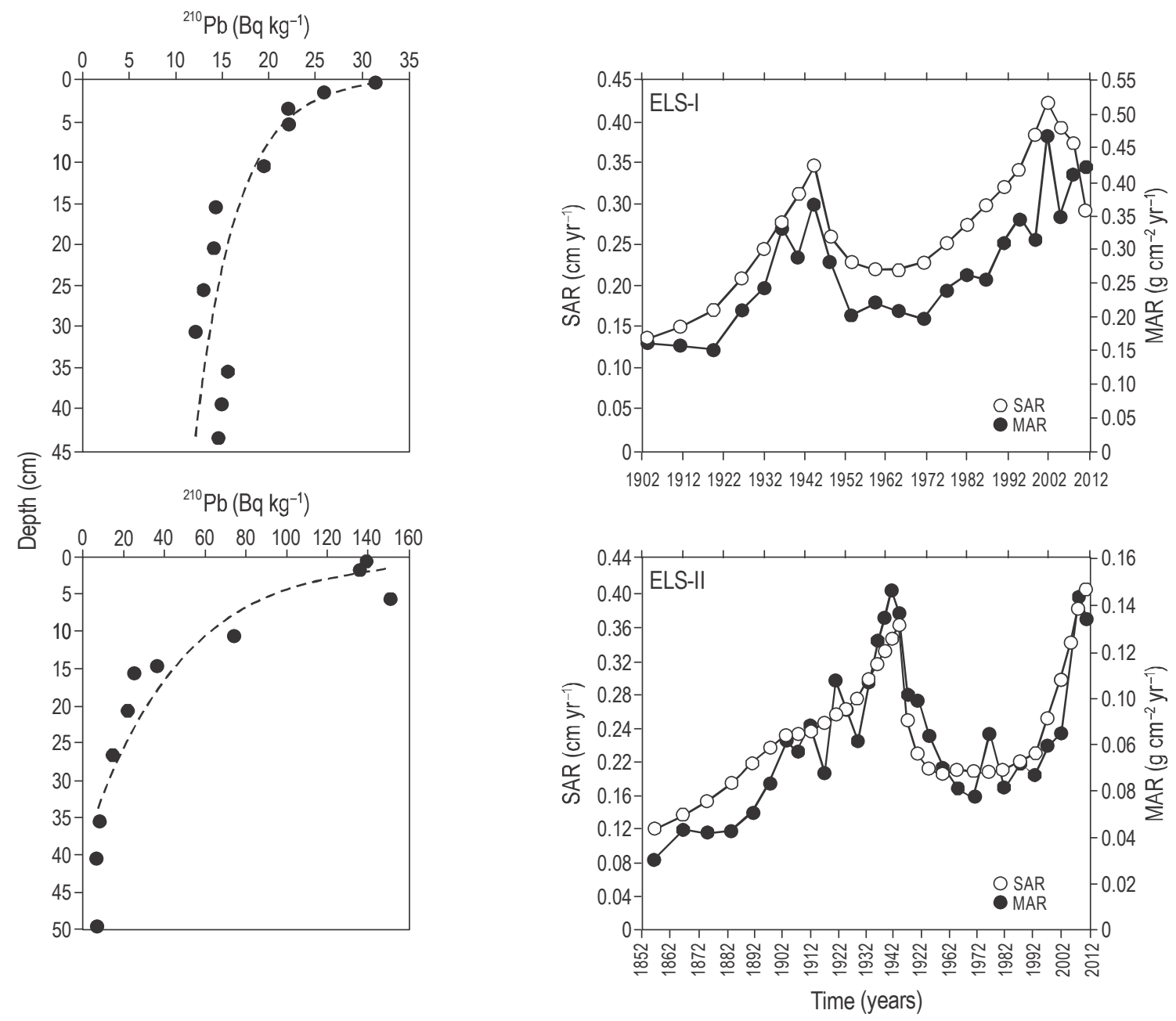

Figure 3. ${ }^{210} \mathrm{~Pb}$ activity profiles relative to depth, and mass accumulation rate (MAR) and sediment accumulation rate (SAR) for the ELS-I and ELS-II cores from Jiquilisco Bay Complex (El Salvador).

Figura 3. Perfiles de actividad de ${ }^{210} \mathrm{~Pb}$ respecto a la profundidad y tasas de acumulación másica (MAR) y sedimentaria (SAR) para los núcleos ELS-I y ELS-II del Complejo Bahía de Jiquilisco, El Salvador.

\section{Geochemical, mineralogical, and micropaleontological characterization of sediment cores}

\section{Site ELS-I (Los Cedrones)}

The ELS-I core sediments were predominantly sandy $(>59 \%)$, with low organic matter $\left(\mathrm{PPI}_{550}<5 \%\right)$ and carbonate $\left(\mathrm{PPI}_{950}<2 \%\right.$ ) contents. The mineral composition was $26-34 \%$ of quartz, $20-30 \%$ of heavy minerals, $16-27 \%$ of plagioclase, $12-26 \%$ of volcanic lithics, and $2-8 \%$ of sedimentary lithics (table 2). The presence of quartz, the high content of heavy minerals (mainly pyroxene and magnetite), and the absence of altered volcanic lithics are indicative of a highenergy depositional environment. Microfossil remains were not found in the sediments.

The grain-size distribution and $\mathrm{Al}$ and $\mathrm{Fe}$ concentration profiles showed little variation with depth. The $\mathrm{Si}$ and $\mathrm{Rb}$ concentrations showed a decreasing trend towards the surface
Las tasas de acumulación másica (TAM) y sedimentaria (TAS) mostraron notables y coincidentes variaciones a lo largo del tiempo en ambos núcleos, y los intervalos de valores obtenidos para los dos núcleos fueron muy similares (fig. 3). En el núcleo ELS-I, las TAM aumentaron de $0.18 \pm$ $0.15 \mathrm{~g} \mathrm{~cm}^{-2}$ año $^{-1}$ (sección $21-22 \mathrm{~cm}$, año 1912) a $0.36 \pm$ $0.05 \mathrm{~g} \mathrm{~cm}^{-2}$ año ${ }^{-1}$ en la sección superficial (año 2011), y se observaron dos máximos pronunciados en 1944 (sección 15-16 cm) y 2002 (sección 3-4 cm). El intervalo de TAS mostró su valor mínimo de $1.2 \pm 0.9 \mathrm{~mm}$ año ${ }^{-1}$ en la sección 20-21 cm (año 1920) y un máximo de $3.4 \pm 0.5 \mathrm{~mm}$ año ${ }^{-1}$ en la superficie del núcleo. Se identificó claramente un máximo en 1944 (3.0 $\pm 0.2 \mathrm{~mm}$ año $\left.{ }^{-1}\right)$, seguido de un incremento casi lineal a partir de 1971 .

En el núcleo ELS-II, las TAM incrementaron de $0.04 \pm$ $0.01 \mathrm{~g} \mathrm{~cm}^{-2}$ año $^{-1}(32-33 \mathrm{~cm})$ a $0.15 \pm 0.01 \mathrm{~g} \mathrm{~cm}^{-2} \mathrm{año}^{-1}$ en la superficie del núcleo (año 2011). Al igual que en el núcleo ELS-I, los valores de las TAM mostraron una tendencia 
of the core, whereas the MS, Ti, and $\mathrm{Zr}$ values showed a decreasing trend with depth (fig. 4). The decrease in $\mathrm{Si}$ and $\mathrm{Rb}$ concentrations and the increase in MS and $\mathrm{Ti}$ and $\mathrm{Zr}$ concentrations indicate the presence of terrigenous sediments from different detrital sources. The concentrations of $\mathrm{Mn}, \mathrm{Br}$, and $\mathrm{Cl}$ increased from the core base to approximately $25 \mathrm{~cm}$ depth, after which the $\mathrm{Br}$ and $\mathrm{Cl}$ concentrations decreased to their minimum value $(6 \mathrm{~cm}$ depth) and then increased towards the surface (fig. 4). The changes in the $\mathrm{Br}$ and $\mathrm{Cl}$ concentrations are likely associated with variations in the input of seawater during the time period covered by the sediment core: the segment with the lowest values of both elements (14-6 cm; i.e., 1954-1965) represents the period of minor marine influence.

\section{Site ELS-II (El Gimidor)}

The ELS-II core sediments were predominantly siltysandy, with sandier clay $(>17 \%)$ at the core base $(30-50 \mathrm{~cm}$ depth) (fig. 4). The sediments had abundant plant remains and considerably high organic matter $\left(\mathrm{PPI}_{550} \geq 16 \%\right)$ and carbonate ( $\mathrm{PPI}_{950} 4-18 \%$ ) percentages. The presence of gypsum and the lowest organic matter and carbonate values were recorded between 20 and $40 \mathrm{~cm}$ depth (figs. 4, 5). The Al, Fe, $\mathrm{Ti}$, and $\mathrm{Zr}$ concentration profiles showed little variation with depth, indicating a constant terrigenous source. In contrast, the $\mathrm{Si}$ and $\mathrm{Rb}$ concentration profiles showed an increasing trend from the base to $30 \mathrm{~cm}$ depth (year 1884) and from $15 \mathrm{~cm}$ depth to the surface, with an intermediate section general creciente hacia la superficie del núcleo, con un máximo pronunciado en el año $1944(15-16 \mathrm{~cm})$. Las TAS aumentaron desde el valor mínimo de $0.8 \pm 0.2 \mathrm{~mm}_{\text {año }}{ }^{-1}$ en 1856 hasta un máximo subsuperficial de $4.0 \pm 0.5 \mathrm{~mm}$ año ${ }^{-1}$ en 1942, luego disminuyeron a $1.6 \pm 0.2 \mathrm{~mm} \mathrm{año}{ }^{-1}$ en 1972, para elevarse de nuevo progresivamente hasta $4.0 \pm 0.4 \mathrm{~mm}_{\text {año }}{ }^{-1}$ en 2009.

\section{Caracterización geoquímica, mineralógica y micropaleontológica de los núcleos sedimentarios}

\section{Sitio ELS-I (Los Cedrones)}

Los sedimentos del núcleo ELS-I fueron predominantemente arenosos $(>59 \%)$, con bajo contenido de materia orgánica $\left(\mathrm{PPI}_{550}<5 \%\right)$ y carbonatos $\left(\mathrm{PPI}_{950}<2 \%\right)$. La composición mineralógica observada fue $26-34 \%$ de cuarzo, $20-30 \%$ de minerales pesados, $16-27 \%$ de plagioclasas, $12-26 \%$ de líticos volcánicos y $2-8 \%$ de líticos sedimentarios (tabla 2). La presencia de cuarzo, el alto contenido de minerales pesados (principalmente piroxenas y magnetitas) y la ausencia de líticos volcánicos alterados son indicativos de un ambiente de depósito de alta energía. No se encontraron restos de microfósiles en los sedimentos.

Los perfiles de distribución de tamaño de grano y las concentraciones de $\mathrm{Al}$ y $\mathrm{Fe}$ mostraron escasa variación con la profundidad. Las concentraciones de $\mathrm{Si}$ y $\mathrm{Rb}$ mostraron una tendencia decreciente hacia la superficie del núcleo, en contraste con los valores de SM y las concentraciones de Ti y $\mathrm{Zr}$

Table 2. Main mineralogical components of the ELS-I and ELS-II cores.

Tabla 2. Principales componentes mineralógicos de los núcleos ELS-I y ELS-II.

\begin{tabular}{|c|c|c|c|c|c|c|}
\hline $\begin{array}{l}\text { ELS-I sediment } \\
\text { section }(\mathrm{cm})\end{array}$ & $\begin{array}{l}\text { Quartz } \\
(\%)\end{array}$ & $\begin{array}{l}\text { Plagioclase } \\
\text { (\%) }\end{array}$ & $\begin{array}{l}\text { Volcanic rock } \\
\text { fragments (\%) }\end{array}$ & $\begin{array}{l}\text { Sedimentary rock } \\
\text { fragments }(\%)\end{array}$ & $\begin{array}{l}\text { Heavy minerals } \\
(\%)\end{array}$ & \\
\hline 10-11 & 34 & 19 & 13 & 8 & 26 & \\
\hline 19-20 & 26 & 16 & 26 & 2 & 30 & \\
\hline $30-31$ & 26 & 19 & 26 & 7 & 22 & \\
\hline $39-40$ & 33 & 27 & 12 & 8 & 20 & \\
\hline $\begin{array}{l}\text { ELS-II sediment } \\
\text { section }(\mathrm{cm})\end{array}$ & $\begin{array}{l}\text { Plagioclase } \\
\text { (\%) }\end{array}$ & $\begin{array}{l}\text { Volcanic rock } \\
\text { fragments (\%) }\end{array}$ & $\begin{array}{l}\text { Altered volcanic } \\
\text { rock fragments (\%) }\end{array}$ & $\begin{array}{c}\text { Ferrocrete } \\
(\%)\end{array}$ & $\begin{array}{l}\text { Gypsum } \\
(\%)\end{array}$ & $\begin{array}{l}\text { Heavy minerals } \\
(\%)\end{array}$ \\
\hline $3-4$ & 30 & 15 & 37 & 15 & 0 & 3 \\
\hline $9-10$ & 46 & 11 & 19 & 20 & 1 & 3 \\
\hline $16-17$ & 59 & 12 & 6 & 15 & 0 & 8 \\
\hline $25-26$ & 39 & 31 & 19 & 4 & 1 & 6 \\
\hline $30-31$ & 42 & 26 & 18 & 3 & 3 & 8 \\
\hline $34-35$ & 37 & 19 & 35 & 4 & 0 & 6 \\
\hline $39-40$ & 13 & 3 & 19 & 0 & 65 & 0 \\
\hline $42-43$ & 36 & 13 & 42 & 5 & 0 & 4 \\
\hline $44-45$ & 34 & 13 & 44 & 4 & 0 & 5 \\
\hline $48-49$ & 32 & 19 & 41 & 5 & 0 & 3 \\
\hline
\end{tabular}


(12-30 cm, 1884-1960) showing an opposite trend. The profiles for Mn concentration, sand percentage, and MS values showed the highest values between the base and $30 \mathrm{~cm}$ depth and the lowest and more homogenous values in the overlying layers. The $\mathrm{Br}$ and $\mathrm{Cl}$ concentration profiles showed quasiconstant values from the base to $30 \mathrm{~cm}$ depth, an increasing trend between 30 and $12 \mathrm{~cm}$ (1960), a decreasing trend between 12 and $3 \mathrm{~cm}$ (1960-2002), and finally an increase towards the surface.

Ten species of benthic foraminifera were found, of which the most abundant were Arenoparella mexicana and Trochamina inflata, both characteristic of brackish environments (estuaries and marshes). Bolivina interjuncta bicostata (Cushman) and Bulimina mexicana Cushman, both of marine origin, were found towards the top of the core. The marine planktonic foraminifera were represented by eight species, all scarce and concentrated in the upper $12 \mathrm{~cm}$. Marine planktonic diatoms were found throughout most of the core, but were slightly more abundant in the upper centimeters.

\section{DISCUSSION}

Despite the sites being located more than $13 \mathrm{~km}$ apart, the MAR and SAR for ELS-I and ELS-II were notably similar, and this was attributed to regional, not local, causes. The abrupt decrease in MAR and SAR at both sites in the early 1950s is most likely related to the construction of the dams along the Lempa River. The surveyed marshes have different geochemical, mineralogical, and micropaleontological characteristics probably because of their different geographical position in the estuarine-lagoon system of the JBC. The ELS-I sediments are coarse, contain quartz and heavy minerals (mainly pyroxene and magnetite), and do not have altered volcanic lithics, indicating a high-energy environment that receives inputs from places nearby, such as the lagoon channels and the barrier to the east of the mouth of the Lempa River. The absence of microfossils is likely due to the highenergy conditions that are not conducive to the preservation of foraminifera whose shells are fragile.

The ELS-II core is rich in organic matter and contains gypsum, plagioclase, and altered volcanic lithics, indicating a low-energy environment, such as lagoons and estuaries (Folk 1980). The absence of quartz and the content of volcanic lithics (altered and unaltered) seems to suggest direct inputs probably from the the Tecapa volcanic complex, which is located less than $20 \mathrm{~km}$ from the site (MARN 2013). The lower energy conditions at ELS-II resulted in better preservation of the micropaleontological record. The analyzed proxies and the ecological preferences of the microorganisms found suggest changes in the environmental conditions across the sedimentary sequence as discussed below:

- From the base of the core to $43 \mathrm{~cm}$ depth, the presence of the benthic foraminifera A. mexicana and T. inflata and of que mostraron una tendencia decreciente con la profundidad (fig. 4). El decremento de las concentraciones de Si y Rb, y el incremento de las concentraciones de $\mathrm{Ti}, \mathrm{Zr}$ y la SM indican la presencia de sedimentos terrígenos que proceden de fuentes detríticas distintas. Las concentraciones de $\mathrm{Mn}, \mathrm{Br}$ y $\mathrm{Cl}$ aumentaron desde el fondo hasta aproximadamente $25 \mathrm{~cm}$ de profundidad, a partir de donde las concentraciones de $\mathrm{Br}$ y Cl decrecieron hasta sus valores mínimos ( $6 \mathrm{~cm}$ de profundidad) para luego incrementarse hacia la superficie (fig. 4). Los cambios en las concentraciones de $\mathrm{Br}$ y $\mathrm{Cl}$ probablemente están asociados a variaciones en el aporte de agua marina durante el periodo de tiempo comprendido en el núcleo sedimentario; es decir, el segmento con los valores mínimos de ambos elementos (14-6 cm; i.e., 1954-1965) representa el periodo de menor influencia marina.

\section{Sitio ELS-II (El Gimidor)}

Los sedimentos del núcleo ELS-II fueron predominantemente limo-arenosos con arcilla (>17\%) y más arenosos en la base (de 30 a $50 \mathrm{~cm}$ de profundidad) (fig. 4). Los sedimentos contuvieron abundantes restos vegetales y presentaron porcentajes considerablemente altos de materia orgánica $\left(\mathrm{PPI}_{550}\right.$ $\geq 16 \%$ ) y de carbonatos ( $\mathrm{PPI}_{950} 4-18 \%$ ). Entre 20 y $40 \mathrm{~cm}$ de profundidad se observó la presencia de yeso, y los valores mínimos de materia orgánica y carbonatos (figs. 4, 5). Los perfiles de concentración de Al, Fe, Ti y Zr mostraron escasa variabilidad con la profundidad, lo cual indica una fuente terrígena constante. En contraste, los perfiles de concentración de $\mathrm{Si}$ y $\mathrm{Rb}$ mostraron tendencias crecientes entre el fondo del núcleo y $30 \mathrm{~cm}$ de profundidad (año 1884) y desde $15 \mathrm{~cm}$ de profundidad hasta la superficie, con una sección intermedia (12-30 cm, 1884-1960) que mostró la tendencia contraria. Los perfiles de concentración de Mn, porcentaje de arenas y valores de SM mostraron los valores más altos entre el fondo y $30 \mathrm{~cm}$ de profundidad, y en las capas suprayacentes se observaron los valores más bajos y homogéneos. Los perfiles de concentración de $\mathrm{Br}$ y $\mathrm{Cl}$ mostraron valores casi constantes desde el fondo del núcleo hasta $30 \mathrm{~cm}$ de profundidad, una tendencia creciente entre 30 y $12 \mathrm{~cm}$ (1960), una tendencia decreciente entre 12 y $3 \mathrm{~cm}$ (1960-2002), y finalmente un incremento hacia la superficie.

Se encontró un total de 10 especies de foraminíferos bentónicos, de las cuales las más abundantes fueron Arenoparella mexicana y Trochamina inflata, ambas características de ambientes salobres (estuarios y marismas). Hacia la cima del núcleo se encontraron especies como Bolivina interjuncta bicostata (Cushman) y Bulimina mexicana Cushman, ambas de origen marino. Los foraminíferos planctónicos (de ambiente marino) estuvieron representados por ocho especies, todas escasas y concentradas en los $12 \mathrm{~cm}$ superiores. Se encontraron diatomeas planctónicas de origen marino a lo largo de la mayor parte del núcleo, pero fueron un poco más abundantes en los centímetros superiores. 


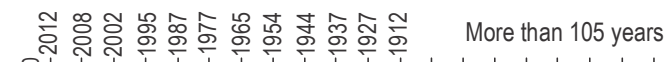
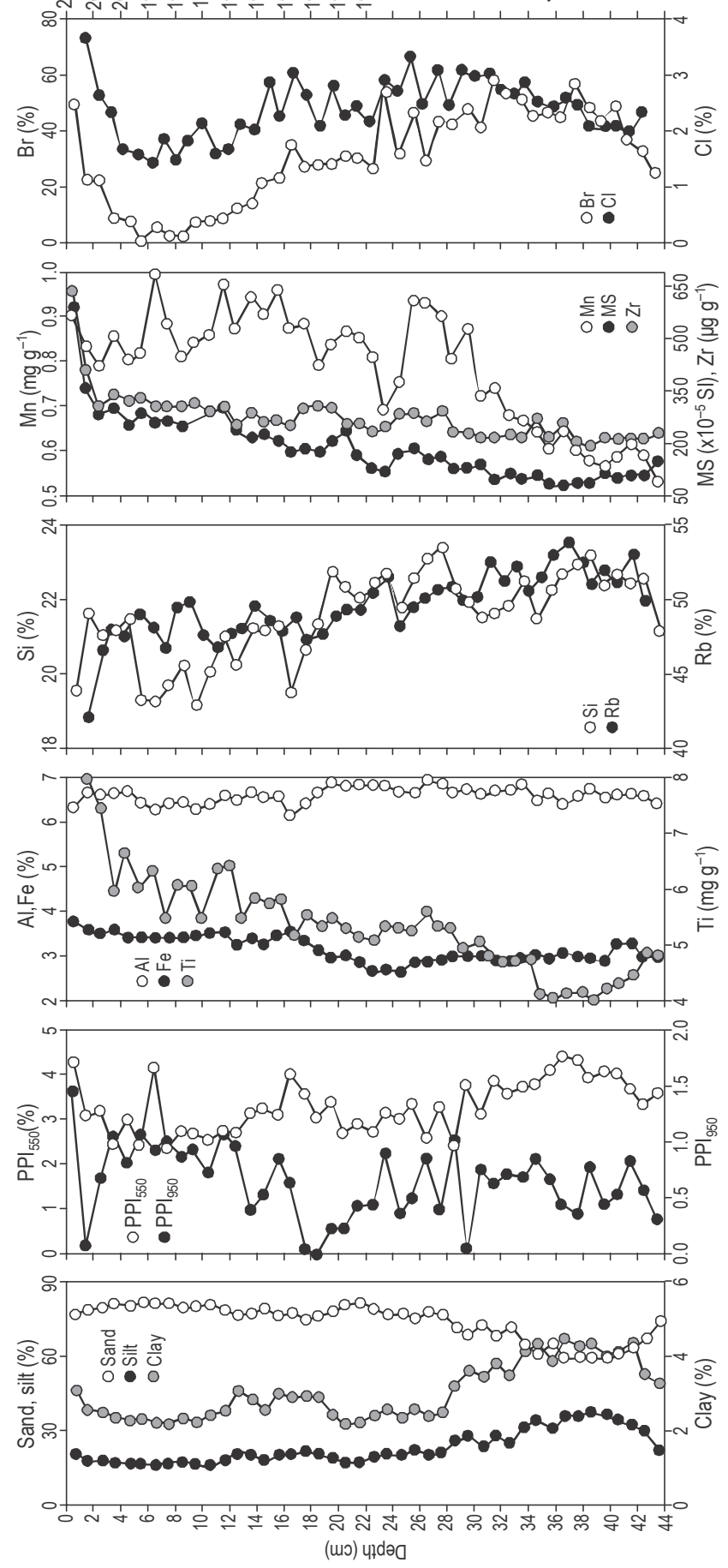
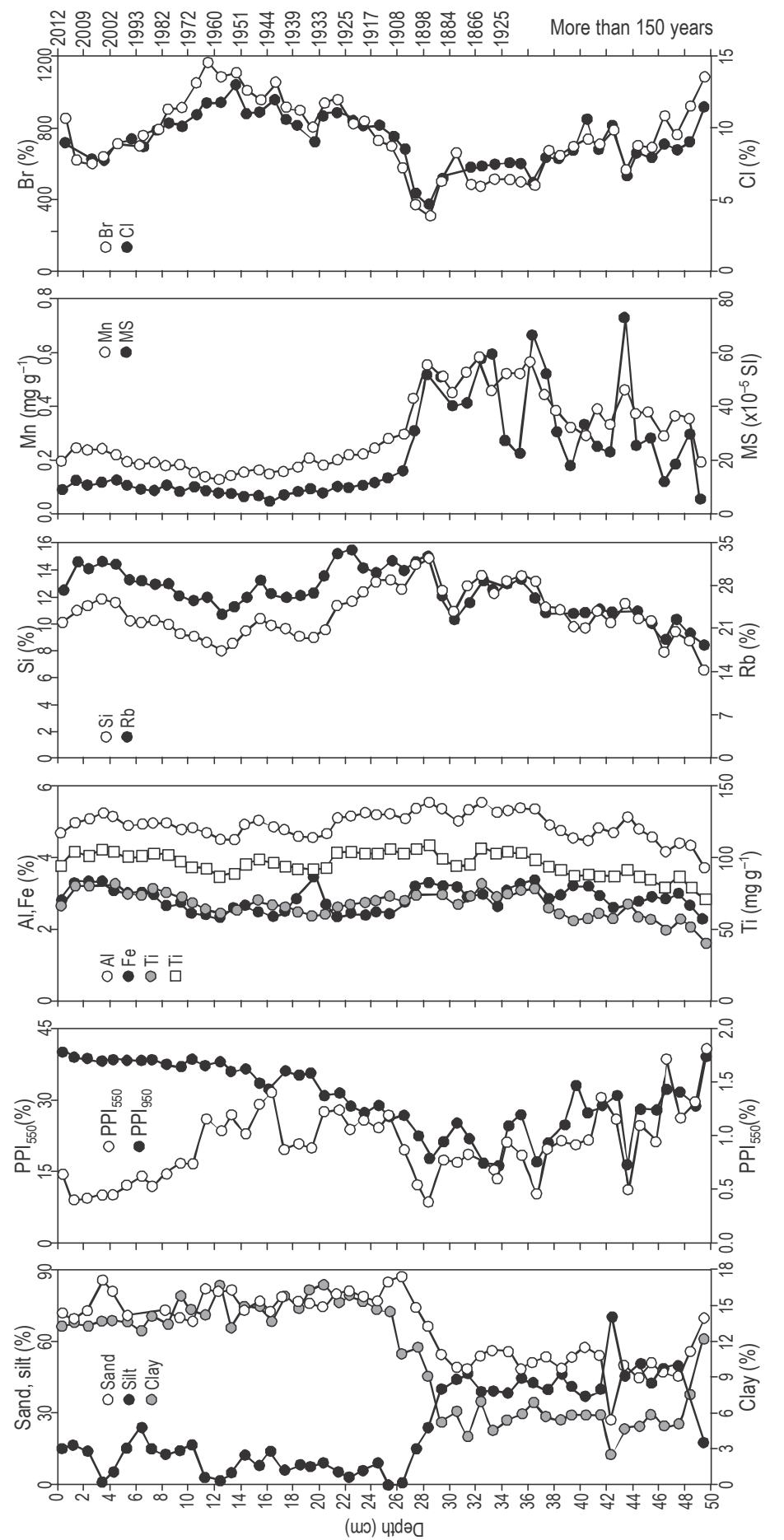

Figure 4. Elemental composition, magnetic susceptibility (MS), grain size, and percentages of $\mathrm{PPI}_{550}$ (organic matter) and $\mathrm{PPI}_{950}$ (carbonates) of the ELS-I and ELS-II cores.

Figura 4. Composición elemental, susceptibilidad magnética (MS), tamaño de grano y porcentajes de $\mathrm{PPI}_{550}$ (materia orgánica) y $\mathrm{PPI}_{950}$ (carbonatos) en los núcleos ELS-I y ELS-II. 


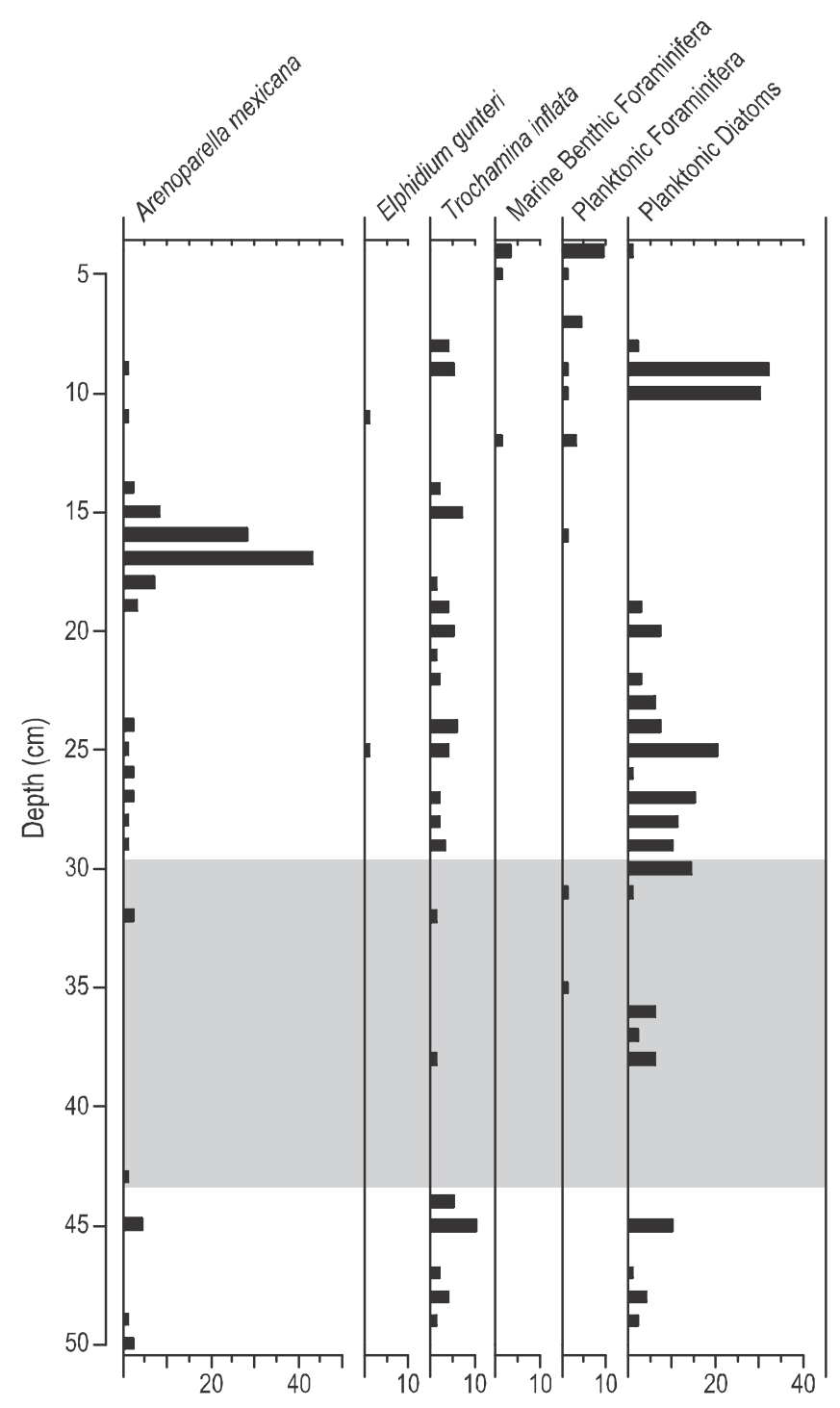

Figure 5. Miocrofaunal content (number of individuals) and presence of gypsum (grey band) in the ELS-II core.

Figura 5. Contenido microfaunístico (número de individuos) y presencia de yeso (banda gris) en el núcleo ELS-II.

Ammobaculites fragments indicates brackish environments of a coastal lagoon. Extrapolating the accretion rates obtained for the past 100 years, these materials were deposted during the second half of the 18th century and beginning of the 19th century.

- From 42 to $29 \mathrm{~cm}$ (until 1884), foraminifera were absent and only some diatoms were present. The presence of gypsum, very abundant in some levels, suggests an evaporitic system, probably caused by a decrease in lagoon depth, with intermittent flooding, as indicated by the core's lowest accretion rates (fig. 3). The Mn concentrations indicate greater oxygenation in this part of the sediment column, confirming subaerial deposition. This section also had the lowest organic matter, carbonate, $\mathrm{Si}$,

\section{DISCUSIÓN}

A pesar de estar separados por más de $13 \mathrm{~km}$, la similitud de los registros de TAM y TAS en ELS-I y ELS-II es notable y fue atribuida a causas regionales y no locales. El decremento abrupto en las TAM y TAS en ambos núcleos a principios de la década de 1950 probablemente esté relacionado con la construcción de las presas en el río Lempa. Las marismas estudiadas presentan características geoquímicas, mineralógicas y micropaleontológicas diferentes, probablemente como resultado de su distinta posición geográfica en el sistema estuarino-lagunar del CBJ. Los sedimentos del núcleo ELS-I son gruesos, contienen cuarzo y minerales pesados (piroxenas y magnetitas principalmente) y no tienen líticos volcánicos alterados, lo cual indica un ambiente de alta energía que recibe aportes de lugares cercanos, tales como los canales lagunares y a la barrera al este de la desembocadura del río Lempa. La ausencia de microfósiles probablemente se debe a la alta energía del ambiente, lo cual no es propicio para la preservación de los foraminíferos cuyas testas son frágiles.

El núcleo ELS-II es más rico en materia orgánica y contiene yesos, plagioclasas y líticos volcánicos alterados que sugieren bajos niveles de energía, como en lagunas y esteros (Folk 1980). La ausencia de cuarzo y su riqueza en líticos volcánicos (alterados y no alterados) parece indicar aportes directos probablemente de los aparatos volcánicos de Tecapa, que se ubican a menos de $20 \mathrm{~km}$ del sitio (MARN 2013). La menor energía del sitio ELS-II permitió una mejor preservación del registro micropaleontológico. Los proxies analizados y las preferencias ecológicas de los microorganismos hallados sugieren cambios en las condiciones ambientales a lo largo de la secuencia sedimentaria, que se describen a continuación:

- De la base del núcleo hasta $43 \mathrm{~cm}$ de profundidad, la presencia de los foraminíferos bentónicos A. mexicana y T. inflata y de fragmentos de Ammobaculites indica ambientes salobres de una laguna costera. Extrapolando las tasas de acreción obtenidas para los últimos 100 años, estos materiales se depositaron desde la segunda mitad del siglo XVIII hasta inicios del siglo XIX.

- De 42 a 29 cm (hasta 1884) no hay foraminíferos, tan sólo algunas diatomeas. La presencia de yeso, en algunos niveles muy abundante, sugiere un sistema evaporítico, probablemente causado por la disminución en la profundidad de la laguna, con inundaciones intermitentes como lo atestiguan las tasas de acreción más bajas de todo el núcleo (fig. 3). Las concentraciones de Mn indican condiciones de mayor oxigenación para esta parte de la columna sedimentaria, lo cual confirma el depósito subaéreo. Se encuentran asimismo los valores más bajos de materia orgánica, carbonatos, $\mathrm{Si}$ y $\mathrm{Rb}$, y los valores más altos de SM que podrían deberse a la mayor 
and $\mathrm{Rb}$ values, as well as the highest MS values, most probably because of the greater abundance of volcanic magnetic minerals (table 2).

- From 28 to $12 \mathrm{~cm}(1892-1955)$, the increased $\mathrm{Br}$ and $\mathrm{Cl}$ concentrations indicate a progressive increase in the salinity of the sediments, suggesting that the site was subject to seawater flooding. This is in agreement with the increased abundance of fine sediments rich in organic matter carried by the water and, consequently, with the progressive increase in accretion rates and the presence of foraminifera that are indicators of lagoon conditions (fig. 5).

- From 11 to $3 \mathrm{~cm}$ (1960-2002), the core presents scant fauna; from 11 to $7 \mathrm{~cm}$, the association is composed of a mixture of lagoon and marine species (fig. 5); and from 6 to $3 \mathrm{~cm}$, the microfauna is slightly more abundant and there are a greater number of marine organisms, indicating greater marine influence. During this period of time, SAR was low. This period coincides with the construction of the dams along the Lempa River, which led to the retention of coarse sediments before reaching the study site. As a result of the reduced sediment input, coastal erosion may have initiated (commonly observed along sand bars and beaches, Bird 2008) and coastal sediments may have been introduced into the area, as suggested by the presence of benthic foraminifera (fig. 5). This could be the origin of the increase in $\mathrm{Si}$ and $\mathrm{Rb}$ concentrations (between 11 and $3 \mathrm{~cm}$, fig. 4) and the dilution of the $\mathrm{Br}$ and $\mathrm{Cl}$ concentrations, though the high concentrations of these two elements continue to indicate the prevalence of marine conditions during this period.

- In the upper part of the core (2003-2011), the accretion rate increases again probably due to the combination of diverse factors, such as greater erosion in the drainage basin related to sea-level rise and changes in land use and agricultural activities (e.g., primarily the cultivation of cotton and sugar cane).

The decrease in Mn concentrations in the uppermost part of the core $(26-0 \mathrm{~cm})$ can be attributed to the low oxygen levels as a result of the high concentrations of organic matter in the sediments (which also explain the low MS values towards the surface of the profile, fig. 4). Reduced conditions are responsible for the dissolution of Mn oxyhydroxides and the diffusion of $\mathrm{Mn}^{2+}$ in pore waters (Farmer and Lovell 1984), and may also cause carbonate dissolution.

Past accretion rates were influenced by hydrological changes, such as sediment retention by the dams built along the Lempa River. Recently, while it has been recognized that global sea-level rise has accelerated over the past century (Church et al. 2013), the local sea-level rise is caused by the interaction of diverse global phenomena (e.g., melting of the abundancia de minerales magnéticos de origen volcánico (tabla 2).

- De 28 a 12 cm (1892-1955), el incremento en las concentraciones de $\mathrm{Br}$ y $\mathrm{Cl}$ señala el aumento progresivo de la salinidad de los sedimentos. Esto indica la inundación del sitio de estudio con aguas marinas, en buen acuerdo con el incremento en la abundancia de sedimentos finos enriquecidos en materia orgánica acarreados por el agua y, consecuentemente, el aumento progresivo de las tasas de acreción y la presencia de foraminíferos indicadores de condiciones lagunares (fig. 5).

- Entre 11 y $3 \mathrm{~cm}$ (1960-2002), el núcleo presenta escasa microfauna; entre 11 y $7 \mathrm{~cm}$, la asociación está compuesta por una mezcla de especies lagunares y marinas (fig. 5); y entre 6 y $3 \mathrm{~cm}$, la microfauna es ligeramente más abundante y presenta mayor número de organismos de origen marino, lo cual sugiere una mayor influencia marina. En este intervalo de tiempo, las TAS muestran valores bajos; este periodo coincide con la construcción de las presas en el trayecto del río Lempa, lo cual ocasionó la retención de sedimentos gruesos, que dejaron de llegar hasta el sitio de estudio. Con la reducción del aporte sedimentario, es probable que haya iniciado un proceso de erosión costera (comúnmente observado en barreras arenosas o playas, Bird 2008) y el aporte de sedimentos costeros al sitio de estudio, tal como lo sugiere la presencia de foraminíferos bentónicos (fig. 5), lo cual podría ser el origen del aumento de las concentraciones de $\mathrm{Si}$ y $\mathrm{Rb}$ (entre $11 \mathrm{y}$ $3 \mathrm{~cm}$, fig. 4) y de la dilución de las concentraciones de $\mathrm{Br}$ y $\mathrm{Cl}$, aunque las altas concentraciones de estos dos últimos elementos siguen indicando la prevalencia de condiciones marinas durante este periodo.

- En la parte superior del núcleo (2003-2011) vuelve a aumentar la tasa de acreción, probablemente debido a una combinación de diversos factores; por ejemplo, una mayor erosión en la cuenca de drenaje, relacionada con cambios en el uso de suelo y actividades agrícolas (e.g., cultivos de algodón y caña de azúcar, principalmente), y el aumento del nivel del mar.

La disminución de las concentraciones de Mn en la parte superficial del núcleo $(26-0 \mathrm{~cm})$ es probablemente resultado de bajas concentraciones de oxígeno, producto de las altas concentraciones de materia orgánica registradas en los sedimentos (las cuales explican también los bajos valores de SM hacia la superficie del perfil, fig. 4). La disolución de oxihidróxidos de $\mathrm{Mn}$ y la difusión de $\mathrm{Mn}^{2+}$ en el agua intersticial es el resultado de condiciones reducidas (Farmer y Lovell 1984), que puede ser también la razón de la disolución de los carbonatos.

En el pasado, las tasas de acreción han sido influenciadas por cambios hidrológicos, como la retención de sedimentos 
polar ice caps and thermal expansion of the oceans) and local phenomena (e.g., tectonic activity and sediment input). The micropaleontological, sedimentological, and geochemical data of the cores collected from two JBC marshes indicate that, in recent years, there has been greater influence of marine conditions in the area. Despite the seismicity of El Salvador, tectonic activity does not apparently directly affect sea-level rise, since the accretion rates obtained for the cores are similar to the global values of sea-level rise proposed by Church et al. (2013).

\section{ACKNOWLEDGMENTS}

This study was financed by the National Council for Science and Technology (CONACYT, Mexico, project CB 2010-153429). The authors thank the National Administration of Aqueducts and Sewers (ANDA, El Salvador) for their help in the topographic survey of the sampling sites, and the following for their assistance: Humberto Bojórquez (analytical work), X Antonio Nava-Fernández (micropaleontological processing), Eduardo Morales and Ricardo Ramírez (sediment analysis), Germán Ramírez and Carlos Suárez (elaboration of maps), and Yaneth Alvarado and Maira Flores (collection of cores).

\section{English translation by Christine Harris.}

\section{REFERENCES}

Bird E. 2008. Coastal Geomorphology: An Introduction. 2nd ed. Wiley, West Sussex, UK, 436 pp.

Cearreta A, Cachao M, Cabral MC, Bao R, Ramalho MJ. 2003. Late glacial and Holocene environmental changes in Portuguese coastal lagoons. 2: Microfossil multiproxy reconstruction of the Santo André coastal area. The Holocene 13: 447-458.

Church JA, Clark PU, Cazenave A, Gregory JM, Jevrejeva S, Levermann MA, Merrifield MA, Milne GA, Nerem RS, Nunn PD, Payne AJ, Pfeffer WT, Stammer D, Unnikrishnan AS. 2013. Sea level change. In: Stocker TF, Qin D, Plattner GK, Tignor M, Allen SK, Boschung J, Nauels A, Xia Y, Bex V, Midgley PM. (eds.), Climate Change 2013: The Physical Science Basis. Contribution of Working Group I to the Fifth Assessment Report of the Intergovernmental Panel on Climate Change. Cambridge University Press, UK, pp. 1137-1216.

Ellwood BB, Crick RE, El Hassani A, Benoist SL, Young RH. 2000. Magnetosusceptibility event and cyclo-stratigraphy method applied to marine rocks: Detrital input versus carbonate productivity. Geology 28: 1135-1138.

Farmer JG, Lovell MA. 1984. Massive diagenetic enhancement of manganese in Loch Lomond sediments. Environ. Technol. Lett. 5: 257-262.

Folk RL. 1980. Petrology of Sedimentary Rocks. Hemphill Publishing Co., Austin, Texas, 182 pp.

Hartmann G. 1956. Zur Kenntnis des Mangrove-Estero-Gebeites von El Salvador und seiner Ostracoden-Fauna. I. Univ. Kiel. Kieler Meeresf. 12: 219-248.

Kemp AC, Telford RJ, Horton BP, Anisfeld SC, Sommerfield CK. 2013. Reconstructing Holocene sea level using salt-marsh foraminifera and transfer functions: Lessons from New Jersey, USA. J. Quat. Sci. 28: 617-629. en las presas construidas en el río Lempa. Recientemente, si bien se ha reconocido que globalmente el nivel del mar ha aumentado durante el último siglo (Church et al. 2013), el ascenso del nivel marino local es resultado de la interacción de diversos fenómenos globales (e.g., el derretimiento de los casquetes polares y la expansión térmica de los océanos) y locales (e.g., la actividad tectónica y el aporte sedimentario). En el CBJ, las evidencias micropaleontológicas, sedimentológicas y geoquímicas de los núcleos recolectados en las dos marismas estudiadas indican que, en los últimos años, ha habido una mayor influencia de condiciones marinas en la zona. A pesar de la sismicidad de El Salvador, parece ser que la actividad tectónica no interviene directamente en la elevación del nivel del mar, ya que las tasas de acreción observadas en los núcleos estudiados son similares a los valores globales de aumento en el nivel del mar propuestos por Church et al. (2013).

\section{Agradecimientos}

Esta investigación fue financiada por el Consejo Nacional de Ciencia y Tecnología (CONACYT, México, proyecto CB 2010-153429). Los investigadores agradecen a la Administración Nacional de Acueductos y Alcantarillados (ANDA) de El Salvador su apoyo en el levantamiento topográfico de los sitios de muestreo, a Humberto Bojórquez en el trabajo analítico, a X Antonio Nava-Fernández en el procesamiento micropaleontológico, a Eduardo Morales y Ricardo Ramírez en el análisis sedimentológico, a Germán Ramírez y Carlos Suárez en la elaboración de mapas, y a Yaneth Alvarado y Maira Flores en la recolección de los núcleos.

Lynch JC, Meriwether JR, McKee BA, Vera-Herrera F, Twilley RR. 1989. Recent accretion in mangrove ecosystems based on ${ }^{137} \mathrm{Cs}$ and ${ }^{210} \mathrm{~Pb}$. Estuaries 12: 284-299.

[MARN] Ministerio de Medio Ambiente y Recursos Naturales. 2013. Geología de El Salvador. MARN, El Salvador. http://www.snet.gob.sv/ver/geologia/geologia+de+el+salvador/

[MARN/AECI] Ministerio de Medio Ambiente y Recursos Naturales/Agencia Española de Cooperación Internacional. 2004. Sitio Ramsar Complejo Bahía de Jiquilisco. MARN, El Salvador. http://www.marn.sv/temas/biodiversidad/humedales/bahia-dejiquilisco.html

Murray JW. 2006. Ecology and Applications of Benthic Foraminifera. Cambridge University Press, UK, 426 pp.

Pattan JN, Masuzawa T, Borole DV, Parthiban G, Jauharil P, Yamamoto M. 2005. Biological productivity, terrigenous influence and noncrustal elements supply to the Central Indian Ocean Basin: Paleoceanography during the past » 1 Ma. J. Earth Syst. Sci. 114: 63-74.

Phleger FB. 1967. Marsh foraminiferal patterns, Pacific coast of North America. An. Inst. Biol. UNAM 38. Serie Ciencias del Mar y Limnología 1: 11-38. 
Potter PE. 1978. Petrology and chemistry of modern big river sands. J. Geol. 86: 423-449.

Ruiz-Fernández AC, Hillaire-Marcel C. $2009 .{ }^{210} \mathrm{~Pb}$-derived ages for the reconstruction of terrestrial contaminant history into the Mexican Pacific coast: Potential and limitations. Mar. Pollut. Bull. 59: 134-145.

Ruiz-Fernández AC, Páez-Osuna F, Urrutia-Fucugauchi J, Preda M. 2005. ${ }^{210} \mathrm{~Pb}$ geochronology of sediment accumulation rates in Mexico City Metropolitan Zone as recorded at Espejo de los Lirios lake sediments. Catena 61: 31-48.

Sadiq M. 1992. Toxic Metal Chemistry in Marine Environments. Marcel Dekker Inc., New York, 390 pp.

Sanchez-Cabeza JA, Ruiz-Fernández AC. 2012. ${ }^{210} \mathrm{~Pb}$ sediment radiochronology: An integrated formulation and classification of dating models. Geochim. Cosmochim. Acta 82: 183-200.

Sanchez-Cabeza JA, Ruiz-Fernández AC, Ontiveros-Cuadras JF, Pérez-Bernal LH, Olid C. 2014. Monte Carlo uncertainty calculation of ${ }^{210} \mathrm{~Pb}$ chronologies and accumulation rates of sediments and peat bogs. Quat. Geochronol. 23: 80-93.

Sandberg P. 1966. The modern ostracods Cyprideis bensoni n. sp. Gulf of Mexico, and C. castus, Baja California. J. Paleontol. 40: 447-449.

Smoak JM, Breithaupt JL, Smith III TJ, Sanders CJ. 2013. Sediment accretion and organic carbon burial relative to sea-level rise and storm events in two mangrove forests in Everglades National Park. Catena 104: 58-66.

[SNET] Servicio Nacional de Estudios Territoriales. 2004. Evaluación de la calidad de agua del rio Grande de San Miguel año 2003. Ministerio de Medio Ambiente y Recursos Naturales, El Salvador. http://www.snet.gob.sv/Hidrologia/icasanmiguel.pdf

Swain FM, Gilby JM. 1967. Ostracoda from Corinto Bay, western Nicaragua, and their relationship to some other assemblages of the Pacific Coast. J. Paleontol. 41: 306-334.

Received September 2014, accepted December 2014. 